\title{
Features and Nutritional Significance of Photosynthates Produced by Unicellular Algae Symbiotic with Larger Foraminifera
}

\author{
B. P. Kremer ${ }^{1}$, R. Schmaljohann ${ }^{2}$ and R. Röttger ${ }^{2}$ \\ 1 Pädagogische Hochschule Rheinland, Seminar für Biologie und ihre Didaktik, GronewaldstraBe 2, D-5000 Köln 41, \\ Federal Republic of Germany \\ 2 Institut für Allgemeine Mikrobiologie der Universität Kiel, Olshausenstraße 40/60, D-2300 Kiel, \\ Federal Republic of Germany
}

\begin{abstract}
Associations of larger Foraminifera with photoautotrophic partners - including representatives of the Bacillariophyceae, Dinophyceae, and Rhodophyceae - have been investigated for their photoassimilatory compounds using ${ }^{14} \mathrm{C}$-tracer techniques. Assimilate patterns are compared with appropriate features of free-living relatives. In the foraminifer-rhodophyteassociation free galactose and glycerol are found which are usually not present in non-symbiotic Rhodophyceae. In the foraminifer-dinoflagellate-association most of the radiocarbon is recovered from lipid compounds, whereas relatively little ${ }^{14} \mathrm{C}$ is found in the soluble carbohydrates. In the foraminifer-diatom-associations the amount of glucose and glycerol is relatively higher than in free-living diatoms. These differences may be interpreted as effects of the symbiotic condition. From the pattern of photoassimilatory products it is concluded that the animal cells receive organic carbon by release of algal assimilates rather than by digestion of their algal symbionts. The endosymbionts of Spirolina arietina were shown to be Rhodophytes.
\end{abstract}

\section{INTRODUCTION}

Endosymbiotic microalgae associated with aquatic invertebrates represent fascinating examples of highly integrative interspecific relationships mutually benefitting both partners involved. In the case of photosynthesizing symbiotic algae it might generally be expected that these autotrophic organisms provide their animal partners with a wide range of accumulated photosynthates. An effective carbon transfer which might even be stimulated by animal tissue, has been demonstrated for a variety of symbiotic associations (Trench, 1979).

While the vast majority of marine coelenterates, for instance, contain dinoflagellate algae (mostly Gymnodinium microadriaticum) as endosymbionts, representatives of the Foraminifera exhibit a remarkable diversity in the choice of their photoautotrophic partners. The yellow-brown endosymbionts (zooxanthellae) of Heterostegina depressa and Amphistegina lessonii have been characterized by fine-structure analysis as diatoms (Berthold, 1978; Schmaljohann and Röttger, 1978). Recently, the diatoms from $H$. depressa and from $A$. lessonii have been isolated in axenic culture (Lee et al., 1979a; Lee et al., 1980a). By means of their frustules they could be identified as Nitzschia valdestriata Aleem and Hustedt and Nitzschia laevis Hustedt ( $H$. depressa and $A$. lessonii from Hawaii) and as Nitzschia panduriformis and Fragilaria sp. (H. depressa and $A$. lessonii from Elat). Species of the same algal class are found in Amphistegina lobifera (Lee et al., 1979a). The zooxanthellae of Amphisorus hemprichii belong to the Dinophyceae (Leutenegger, 1977a). The algae associated with Peneroplis planatus and $P$. pertusus are unicellular Rhodophyceae (Leutenegger, 1977b), representing the only hitherto known examples of endosymbiotic red algae. The zoochlorellae of other species of larger Foraminifera have been shown to be Chlamydomonas spp. (Lee et al., 1974, 1979b). The symbionts of Spirolina arietina have not yet been identified, but their red colouration as well as our findings (see below) enable us to classify them as Rhodophytes. Recently, some benthic Foraminifera have even been reported to be associated with algal chloroplasts (Lopez, 1979).

The notable range of algal endosymbionts from different classes require further evaluation with particular regard to the metabolism of photoassimilatory products. Results on the physiology of several species of larger Foraminifera are in press (Lee et al., 1980b). No 
further biochemical or physiological characterization of these associations has so far been reported.

\section{MATERIAL AND METHODS}

Some 5-30 individuals of Heterostegina depressa d'Orbigny, Amphistegina lessonii d'Orbigny, Amphistegina lobifera Larsen, Amphisorus hemprichii Ehrenberg, Peneroplis pertusus Forskål and Spirolina arietina Batsch were used for the experiments. $P$. pertusus, $S$ arietina, Aphisorus hemprichii and Amphistegina lobifera were collected in rockpools at Makapuu Point, Oahu, Hawaii. Amphistegina lessonii derives from clone cultures whose stock material is also from the Makapuu pools. Heterostegina depressa cultivated in Kiel are part of a clone originating from a microspheric parent individual collected off Maui, Hawaii (for culture methods see Röttger, 1972).

The test individuals were incubated in light (5000 lx) in a $\mathrm{H}^{14} \mathrm{CO}_{\overline{3}}$-seawater medium $\left(100 \mu \mathrm{Ci} \mathrm{ml^{-1 }}\right)$ and were then analyzed for distribution of ${ }^{14} \mathrm{C}$ in the major photosynthates by means of chromatographic techniques. Cultures of Prorocentrum micans Ehrenberg and Scrippsiella faeroense (Paulsen) Balech and Soares, kindly supplied by Dr. E. Hagmeier (Biologische Anstalt Helgoland), were treated in the same way. All analytical procedures used have been detailed in a recent review (Kremer, 1978a).

\section{RESULTS AND DISCUSSION}

All foraminiferans investigated incorporated appreciable amounts of ${ }^{14} \mathrm{C}$ in the light, due to photosynthetic carbon fixation by their endosymbiotic algae. Assimilation rates for the endosymbiotic algae of Heterostegina depressa account for $130 \mathrm{nmol} \mathrm{CO}_{2} \mu \mathrm{g}^{-1} \mathrm{Chl}$ a $h^{-1}$. Similar rates have been observed in the other associations investigated. Radiocarbon was recovered from various compounds soluble in a mixture of methanol-chloroform-formic acid $(12: 5: 2)$ and ethanol $(50 \%)$ as well as from insoluble (polymeric) compounds. Some of the major assimilates of the neutral fraction and percentages of ${ }^{14} \mathrm{C}$-labelling are listed in Table 1

Since the typical patterns of accumulated photoassimilatory products provide a useful biochemical marker for taxonomic purposes (Kremer, 1978b, c), the results obtained are first to be interpreted from this point of view. In the foraminiferan harboring unicellular red algae, the strongest ${ }^{14} \mathrm{C}$-labelled low-molecular weight carbohydrate has been identified as floridoside (2-0-D-glycerol- $\alpha$-D-galactopyranoside). This finding is consistent with earlier observations on a wide variety of marine red algae (Kremer, 1978b) and on freeliving unicellular species (Kremer and Feige, 1979). The taxonomic identity of the endosymbionts of Spirolina arietina was hitherto unknown. However, the pattern of their photoassimilatory products (which is very similar to that of Peneroplis pertusus) allows to identify them as Rhodophytes.

The assimilate pattern of the dinophycean endosymbionts of Amphisorus hemprichii compares well with the appropriate features of planktonic dinoflagellates, such as Prorocentrum micans and Scrippsiella faeroense, where glucose and glycerol are usually the predominantly ${ }^{14} \mathrm{C}$-labelled carbohydrate compounds (Table 2). As in A. hemprichii, the assimilates provided by symbiotic diatoms of Heterostegina depressa and Amphistegina spp. comprise glucose along with glycerol and thus resemble qualitatively those of other species of Bacillariophyceae in the free-living state (Table 2, cf. Kremer and Berks, 1978). Symbiotic unicellular algae, therefore, appear to show the same pattern of accumulated compounds as their free-living relatives.

However, the quantitative and qualitative analysis of assimilate patterns from symbiotic associations im-

Table 1. Distribution of photosynthetically assimilated ${ }^{14} \mathrm{C}(3 \mathrm{~h})$ among neutral constituents of symbiotic associations $\left(\% / \mathrm{of}{ }^{14} \mathrm{C}\right.$ labelling). - not traced

\begin{tabular}{|c|c|c|c|c|c|c|}
\hline $\begin{array}{l}\text { Foraminifera species: } \\
\text { Class of symbionts: }\end{array}$ & $\begin{array}{c}\text { Amphistegina } \\
\text { lessonii }\end{array}$ & $\begin{array}{c}\text { Amphistegina } \\
\text { lobifera } \\
\text { Bacillariophyceae }\end{array}$ & $\begin{array}{l}\text { Heterostegina } \\
\text { depressa }\end{array}$ & $\begin{array}{l}\text { Amphisorus } \\
\text { hemprichii } \\
\text { Dinophyceae }\end{array}$ & $\begin{array}{l}\text { Peneroplis } \\
\text { pertusus } \\
\text { Rhodo }\end{array}$ & $\begin{array}{l}\text { Spirolina } \\
\text { arietina } \\
\text { ceae }\end{array}$ \\
\hline Soluble photosynthates: & 69.6 & 61.4 & 89.5 & 81.6 & 79.1 & 71.2 \\
\hline Insoluble photosynthates: & 30.4 & 38.5 & 10.5 & 18.4 & 20.9 & 28.3 \\
\hline \multicolumn{7}{|c|}{ Soluble compounds $=100 \%$} \\
\hline Glycerol & 4.7 & 6.7 & 10.9 & 3.5 & 7.8 & 5.1 \\
\hline Galactose & - & - & - & - & 5.6 & 4.9 \\
\hline Floridoside & - & - & - & - & 18.1 & 14.4 \\
\hline Glucose & 11.5 & 6.3 & 4.0 & 5.2 & - & - \\
\hline Polyglucan & 44.6 & 17.8 & 42.7 & 1.4 & 11.9 & 34.4 \\
\hline Lipids & 31.0 & 51.0 & 32.8 & 73.7 & 19.4 & 5.7 \\
\hline
\end{tabular}


Table 2. Distribution of photosynthetically assimilated ${ }^{14} \mathrm{C}(3 \mathrm{~h})$ among neutral assimilates of free-living relatives of symbiotic algae $\left(\%\right.$ of ${ }^{14} \mathrm{C}$-labelling): - not traced

\begin{tabular}{|c|c|c|c|c|c|c|c|}
\hline & \multicolumn{3}{|c|}{ Bacillariophyceae $^{1}$} & \multicolumn{2}{|c|}{ Dinophyceae } & \multicolumn{2}{|c|}{ Rhodophyceae $^{2}$} \\
\hline & $\begin{array}{c}\text { Navícula } \\
\text { pelliculosa }\end{array}$ & $\begin{array}{c}\text { Nitzschia } \\
\text { palea }\end{array}$ & $\begin{array}{c}\text { Phaeodactylum } \\
\text { tricornutum }\end{array}$ & $\begin{array}{l}\text { Prorocentrum } \\
\text { micans }\end{array}$ & $\begin{array}{c}\text { Scrippsiella } \\
\text { faeroense }\end{array}$ & $\begin{array}{l}\text { Porphyridium } \\
\text { cruentum }\end{array}$ & $\begin{array}{l}\text { Rhodella } \\
\text { violacea }\end{array}$ \\
\hline Soluble photosynthates: & 79.1 & 67.7 & 68.0 & 88.7 & 82.3 & 85.2 & 78.2 \\
\hline Insoluble photosynthates: & 21.9 & 32.3 & 32.0 & 11.3 & 17.6 & 14.8 & 22.8 \\
\hline \multicolumn{8}{|l|}{ Soluble compounds $=100 \%$} \\
\hline Glycerol & 1.8 & 1.0 & 2.4 & 8.2 & 9.5 & - & - \\
\hline Galactose & - & - & - & - & - & - & - \\
\hline Floridoside & - & - & - & - & - & 52.1 & 45.3 \\
\hline Glucose & 1.0 & 1.0 & 1.4 & 22.9 & 35.7 & - & - \\
\hline Polyglucan & 22.9 & 30.4 & 26.5 & 10.2 & 13.1 & 5.7 & 9.2 \\
\hline Lipids & 68.4 & 54.9 & 52.8 & 18.4 & 14.5 & 8.5 & 13.3 \\
\hline
\end{tabular}

plies further aspects, when compared to the appropriate features of nonsymbiotic algae. It is noteworthy that in extracts prepared from Peneroplis pertusus and Spirolina arietina appreciable amounts of ${ }^{14} \mathrm{C}$-galactose and ${ }^{14} \mathrm{C}$-glycerol are found in addition to the heteroside composed of both compounds. Free galactose and glycerol are usually not encountered in nonsymbiotic Rhodophyceae (Kremer, 1978b, ci Kremer and Feige, 1980). In a first approach, the occurrence of these compounds may be interpreted as an effect of the symbiotic condition. While floridoside is clearly stored inside red-algal endosymbionts and has hitherto never been observed as extracellular product, galactose and glycerol are most probably constituents of the animal cell and hence reflect to some extent the metabolization of floridoside derived from the plant cell. At present it is not possible to decide whether floridoside is released from the algal endosymbionts (which might be impeded by the molecular size of this compound) or whether galactose and glycerol are transferred immediately.

A similar situation is observed in Foraminifera containing symbiotic diatoms: The amount of ${ }^{14} \mathrm{C}$-labelled glycerol (exceeding $4 \%$ ) in these associations is far more than that observed in a variety of free-living species (Table 2). The same is true for ${ }^{14} \mathrm{C}$-glucose, in Navicula spp. and Nitzschia spp. for instance, is in the range of detection limits after long periods of incubation in light. Distinct ${ }^{14} \mathrm{C}$-labelling of these compounds may, therefore, be indicative of metabolic participation of the animal partner. The symbiotic dinoflagellates of Amphisorus hemprichii incorporate relatively less ${ }^{14} \mathrm{C}$ into glucose and glycerol than do Prorocentrum micans and Scrippsiella faeroense.

In all associations, except with Amphisorus hemprichii, a remarkable amount of ${ }^{14} \mathrm{C}$ is confined to soluble, but chromatographically immobile, material yielding
${ }^{14} \mathrm{C}$-glucose upon hydrolysis, and is hence regarded as a glucan-type polysaccharide. This as well as the fraction of insoluble assimilates is usually more intensely ${ }^{14} \mathrm{C}$-labelled than in free-living algae incubated under comparable conditions. Most of the photosynthetically fixed radiocarbon is recovered from lipid compounds in $A$. hemprichii, whereas relatively little ${ }^{14} \mathrm{C}$ is found in the soluble carbohydrates.

There are two principal ways for the animal partner to obtain assimilates from its endosymbiotic primary producers. The surplus production of assimilates is (i) released from the algae and thus flows from plant to animals cells, or (ii) endosymbionts are digested. Enzymatic degradation of algal storage assimilates in the course of digestion would thus yield ${ }^{14} \mathrm{C}$-glycerol (from the lipid fraction; Table 1) and ${ }^{14} \mathrm{C}$-glucose (from the glucan-type polysaccharides). However, ${ }^{14} \mathrm{C}$-glucose does not occur in Peneroplis pertusus and Spirolina arietina, though a strongly ${ }^{14} \mathrm{C}$-labelled glucan-fraction is available. On the other hand, the amount of ${ }^{14} \mathrm{C}$ glucose found in Amphisorus hemprichii does not correspond to the ${ }^{14} \mathrm{C}$-labelling of glucans in this association. Moreover, in the symbiotic algae of $P$. pertusus and $A$. hemprichii, for instance, percentage labelling of usually accumulated compounds (such as floridoside and glucose) is to some extent lower than in nonsymbiotic relatives.

The features of distribution of radiocarbon among soluble and polymeric material as detailed above reflect the metabolic participation of the animal host and may thus include different rates of turnover in different associations. Nonetheless, it is reasonable to assume that the foraminiferans receive algal photoassimilatory products by carbon transfer involving at least accumulated compounds or their biosynthetic precursors $\left({ }^{14} \mathrm{C}\right.$-glycerol in case of diatoms).

However, in Heterostegina depressa and probably 
also in other foraminiferans, digestion of endosymbiotic algae is possible. Continuous observations show that they often release appreciable amounts of browngreen waste material. While in some species this might originate from the digestion of external food, in $H$. depressa it clearly represents the remains of digested endosymbiotic algae. This has been shown by electron microscopy and demonstration of acid phosphatase within the digestion vacuoles (Schmaljohann, unpublished).

Acknowledgements. We are thankful to Barbara J. Lee of the Blue-Water Marine Laboratory (University of Hawaii, USA) for sending animal material. The US Coast Guard kindly provided access to the rockpools at Makapuu Point, Oahu, Hawaii. We also gratefully acknowledge the help of A. Irwan in culture work. Thanks are due to Dr. A. Lévy (Paris) and Dr. C. Ross (Washington) for identification of Amphisorus hemprichii, and to Prof. J. Willenbrink (Köln, FRG) for providing laboratory facilities. Dr. J. W. Markham (Helgoland) kindly revised the English version of this manuscript.

\section{LITERATURE CITED}

Berthold, W.-U. (1978). Ultrastrukturanalyse der endoplasmatischen Algen von Amphistegina lessonii d'Orbigny, Foraminifera (Protozoa) und ihre systematische Stellung. Arch. Protistenkde. 120: 16-62

Kremer, B. P. (1978a). Determination of photosynthetic rates and ${ }^{14} \mathrm{C}$ photoassimilatory products of brown seaweeds. In: Hellebust, J. A., Craigie, J. S. (eds) Handbook of phycological methods, Vol. II. Cambridge University Press, Cambridge, pp. 269-283

Kremer, B. P. (1978b). Patterns of photoassimilatory products in Pacific Rhodophyceae. Can. J. Bot. 56: 1655-1659

Kremer, B. P. (1978c). Studies on ${ }^{14} \mathrm{CO}_{2}$-assimilation in marine Rhodophyceae. Mar. Biol. 48: 47-55
Kremer, B. P., Berks, R. (1978). Photosynthesis and carbon metabolism in marine and freshwater diatoms. Z. Pflanzenphysiol. 87: 149-167

Kremer, B. P., Feige, G. B. (1979). Accumulation of photoassimilatory products by phycobiliprotein-containing algae with special reference to Cyanidium caldarium. Z. Naturforsch. 34c: 1209-1214

Lee, J. J., Crockett, L. J., Hagen, J., Stone, R. J. (1974). The taxonomic identity and physiological ecology of Chlamydomonas hedleyi sp. nov., algal flagellate symbiont from the foraminifer Archaias angulatus. Br. phycol. J. 9: $407-422$

Lee, J. J., McEnery, M. E., Shilo, M., Reiss, Z. (1979a). Isolation and cultivation of diatomsymbionts from larger Foraminifera (Protozoa). Nature, Lond. 280, 57-58

Lee, J. J., McEnery, M. E., Kahn, E., Shuster, F. (1979b). Symbiosis and the evolution of larger Foraminifera. Micropaleontology 25 (2): 118-140

Lee, J. J., McEnery, M. E., Röttger, R., Reimer, C. W. (1980a). The isolation, culture, and identification of endosymbiotic diatoms from Heterostegina depressa and Amphistegina lessonii (Larger Foraminifera) from Hawaii. Bot. Mar. (in press)

Lee, J. J., McEnery, M. E. and Garrison, J. (1980b). Experimental studies or larger Foraminifera and their symbionts from the Gulf of Eilat. J. Foraminiferal Res. (in press)

Leutenegger, S. (1977a). Ultrastructure and motility of dinophyceans symbiotic with larger, imperforated Foraminifera. Mar. Biol. 44: 157-164

Leutenegger, S. (1977b). Ultrastructure de foraminifères perforés et imperforés ainsi que de leurs symbiotes. Cahiers de Micropaléontologie 3: 1-55

Lopez, E. (1979). Algal chloroplasts in the protoplasm of three species of benthic Foraminifera: taxonomic affinity, viability and persistence. Mar. Biol. 53: 201-211

Röttger, R. (1972). Die Kultur von Heterostegina depressa (Foraminifera: Nummulitidae). Mar. Biol. 15: 150-159

Schmaljohann, R., Röttger, R. (1978). The ultrastructure and taxonomic identity of the symbiotic algae of Heterostegina depressa (Foraminifera: Nummulitidae). J. mar. biol. Ass. U.K. 58: $227-237$

Trench, R. K. (1979). The cell biology of plant-animal symbiosis. Ann. Rev. Plant Physiol. 30: 485-531

This paper was submitted to the editor; it was accepted for publication on January 10, 1980. 